\title{
What role for housing in the 'Brexit' election? Spotlight on the party manifestos and what they mean for the housing sector
}

\author{
Tracy Harrison* \\ Northern Housing Consortium
}

\begin{abstract}
It is worthwhile to reflect that it is only just over two years since the last General Election and yet so much has changed for the social housing sector in that short time, driven in part by the terrible tragedy of the Grenfell fire which will fundamentally change both the regulation of building safety and the relationship between tenant and landlord. As the pressure on access to good quality, affordable housing continues to exert influence over policy makers, we assess the manifestos for their response to the ongoing crisis of homelessness, and poor-quality living conditions particularly in the private rented sector.
\end{abstract}

The main parties all promise to increase the number of new homes built, but with different emphasis on whether this is private, social or affordable housing. All pledge to end rough sleeping within a Parliamentary term, and all include proposals aimed to enable longer and more secure private tenancies, including an end to no-fault evictions, and to strengthen the rights of social tenants.

The biggest change since the last election is the extent to which carbon reduction policy has reached the top of the agenda for the main parties, instead of being the focus of smaller parties.

With multibillion-pound pledges coming thick and fast and promises of a Green Revolution and a council house building Renaissance, we have looked at the main party manifestos to see where they diverge or converge on housing policies, and, in particular, what their pledges may mean for housing providers in the North of England.

\section{Delivery of Affordable Housing}

As the manifestos emerged, the attention-grabbing housing headlines were around the housing delivery ambitions with some eye-watering numbers being proposed.

The Liberal Democrats were first out of the trap with their manifesto "Stop Brexit: Build a Brighter Future" committing to new direct spending on housebuilding to help build 300,000 homes a year by 2024 , including 100,000 social homes.

While the numbers of social housing promised by the Liberal Democrats were promising, they were overshadowed by Labour's manifesto "It's Time for a Real Change" promising to build more than a million homes over a decade with council housebuilding at the forefront. Their annual target would be 150,000 social homes, with 100,000 of these built by councils for social rent in the "biggest council housebuilding programme in more than a generation." The manifesto confirms these 
p. 90. What role for housing in the 'Brexit' election? Spotlight on the party manifestos and what they mean for the housing sector

homes would be made available in every area. This would be funded with $£ 75 \mathrm{bn}$ of grant over 5 years from a proposed $£ 150$ bn Social Transformation Fund.

This would be a vast increase on current social house building by councils which was just a few thousand last year. The figure is based on the estimates set out in the Shelter Report 'A Vision for Social Housing' which calls for an average of 155,000 more social homes a year. This would mean that social housing delivery would account for most of the housebuilding each year.

The capacity of local authority housing services has been significantly depleted in the last decade and it must be assumed that Labour is aware that the capacity currently doesn't exist to deliver at such scale. Housing, planning and development services have experienced some of the deepest and most sustained reductions in capacity of any local authority service area. Nevertheless, the ambition is to be welcomed as it raises the bar significantly on a much-needed resource.

Labour also plan to build more low-cost homes reserved for first-time buyers in every area and build new discount homes with prices linked to local incomes. Under Labour the definition of "affordable" would be modified so that it is based on local incomes. Help to Buy would be reformed to focus on first-time buyers on "ordinary" incomes. They also aim to end the sale of new leasehold properties, abolish unfair fees and conditions, and give leaseholders the right to buy their freehold at a price they can afford.

To stop the 'haemorrhage' of low-cost homes, they would end the Right to Buy. This differs from the other two parties as the Liberal Democrats would devolve control to local councils and would introduce a new Rent to Own model for social housing where rent payments give tenants an increasing stake in the property, owning it outright after 30 years. The Conservatives pledge to continue Right to Buy and introduce further pilots of the voluntary Right to Buy for housing association tenants.

Labour aims to create a new Department for Housing, make Homes England more accountable and would introduce an English Sovereign Land Trust to be able to buy land cheaper. This would also include new "use it or lose it" taxes on developers for stalled housing developments and make brownfield sites the priority for development while protecting the green belt.

The Conservative manifesto, 'Get Brexit Done Unleash Britain's Potential' maintained a 'steady-as-you-go' approach continuing with support for homeownership, and a target of 300,000 homes a year by the mid-2020s, while continuing to protect the Green Belt.

Importantly, they have committed to renewing the Affordable Homes Programme which is due to end in 2021, in order to support the delivery of "hundreds of thousands of affordable homes". However, they have not set a specific social housing target, as the other two parties have done.

Social housing providers in the North are ambitious to support the delivery of greater numbers of affordable housing but have said there needs to be significant additional grant investment to boost supply. The Affordable Homes Programme is the main lever to do this. It is currently not restricted to any geographic area (as other funding programmes are) and provides a significant source of funding for Northern development. In recent years, 1 in 3 affordable homes built with the support of grant funding have been in the Northern regions and this must continue to be the case under any expanded programme. Affordable housing grants also fulfil many other roles, including a more flexible and holistic funding regime - directing funding at issues like stock renewal, infrastructure and unlocking difficult sites. 
p. 91. What role for housing in the 'Brexit' election? Spotlight on the party manifestos and what they mean for the housing sector

The Conservative manifesto offers support for home ownership in several ways. First time buyers would be offered new fixed rate mortgages which reduce the level of deposit required; the Help to Buy scheme is extended from 2021 to 2023; shared ownership is extended and reformed and a First Home scheme would enable councils to use developers' contributions via the planning process to discount homes in perpetuity by a third for local people or key workers. This has echoes of David Cameron's promised 200,000 Starter Homes at a discount which was abandoned as the discount was set too widely. This new scheme has been made more palatable by being limited to only 19,000 homes by the mid-2020s. They also propose to make the planning system simpler and support modern methods of construction.

Leasehold reforms will continue including implementing a ban on the sale of new leasehold homes, restricting ground rents to a peppercorn, and providing necessary mechanisms of redress for tenants.

The pledges from both Labour and Liberal Democrats to deliver social housing at scale is a necessary and welcome shift in policy. All local authority areas in the North report a shortage of affordable housing. Just under 20,000 affordable homes are needed across the North of England every year representing a large shortfall with the consequent impact on homelessness, overcrowding and waiting lists for social housing. We would aim to see the Conservative commitments include a target for affordable housing as the other main parties have done.

The Northern Housing Consortium supports the calls by national housing sector bodies for a ten-year investment programme for social and affordable housing. The cost of this programme is estimated at $£ 12.8 \mathrm{bn}$ per year. As noted above, the Affordable Homes Programme has delivered affordable housing completions in Northern areas, and we believe any expanded programme should ensure this proportion is maintained with a fair and geographically even approach. This is not only important for Northern communities but makes a critical contribution to any incoming government's overall housing supply ambitions.

\section{Raising Housing Standards}

\section{Climate Change}

All parties commit to targets for net zero carbon emissions from homes. The ambitions for reducing emissions from homes are challenging and will require investment from an incoming government. The detail of this and how the housing sector can lead the way on reducing greenhouse gas emissions is one of the biggest priorities for the housing sector and so this policy development should be watched with interest.

One of the key risks to achieving the government's target of 'Net Zero by 2050' would be failure to adapt homes which account for 18 per cent of total UK emissions. To meet the net-zero carbon target requires largely eliminating emissions from all homes.

The Committee for Climate Change recommend that 'by 2025 at the latest, no new homes should connect to the gas grid.' This date is reflected in the government's current proposal for a Future Homes Standard for all new housing.

Labour's manifesto launches a Green New Deal. Labour dropped the overly ambitious target to achieve net zero by 2030 and now talks about net-zero emissions within the 2030s with a pledge to deliver nearly 90 per cent of electricity and 50 per cent of heat from renewable and low-carbon sources by 2030. 
p. 92. What role for housing in the 'Brexit' election? Spotlight on the party manifestos and what they mean for the housing sector

They aim to introduce a zero-carbon homes standard for all new homes and upgrade almost all the UK's existing 27 million homes to the highest energy-efficiency standards with the aim of eliminating fuel poverty. They would support the roll out of heat pumps, solar hot water and hydrogen, and investment in district heat networks using waste heat.

The Liberal Democrats included an emergency ten-year programme including requiring all new homes to be built to a zero-carbon standard by 2021 and Passivhaus standard by 2025 and would pilot a new subsidised Energy-Saving Homes scheme with means tested free retrofits. A zero-carbon heat strategy would see the phased installation of heat pumps in homes off the gas grid and they would aim to insulate all of Britain's homes by 2030.

Funding for this will come from a $£ 5 b n$ investment for a new Green Investment Bank to use public money to attract private investment for zero-carbon priorities. They plan to impose a statutory duty on all local authorities to produce a Zero Carbon Strategy.

The Conservative manifesto restates the target of reaching Net Zero by 2050 with investment in clean energy solutions and green infrastructure. This promises to lower energy bills funded through capital investment of a 'social housing decarbonisation fund' over the next four years. Existing pledges include the Future Homes Standard to decarbonise new homes from 2025 but is silent on the retrofitting of existing homes.

We welcome a commitment in the Conservative manifesto for a social housing decarbonisation fund amounting to $£ 710$ m over 4 years in addition to a public sector decarbonisation scheme. However, current estimates show that cost effective improvements to existing social rented housing alone would cost $£ 3.8 \mathrm{bn} .{ }^{1}$ Similarly, Labour's commitment to retrofit 27 million existing homes is good to see but poses more questions than answers in terms of funding, capacity and supply. Northern areas have a legacy of concentrations of older terraced housing stock throwing up significant challenges in reducing emissions. A substantial flexible renewal fund year-on-year will be needed to allow Northern towns and cities to raise the quality of the existing housing stock and reach a fit-for-future standard.

\section{Building Safety}

It must be expected that any new government will focus heavily on building safety regulations and will act quickly on implementing the findings of the Hackitt Inquiry which published its phase 1 report on 31 October.

Prior to the announcement of the General Election, the government had already committed to implementing the recommendations in full and had promised a Building Safety Bill.

Their manifesto reiterates this commitment to implementing and legislating for all the recommendations of the Hackitt Review and the first phase of the independent inquiry. They have also pledged to continue the testing process of materials used in cladding.

A Labour government would introduce a $£ 1$ bn Fire Safety Fund to "fit sprinklers and other fire safety measures in all high rise council and housing association tower blocks, enforce the replacement of Grenfell-style cladding, while introducing mandatory building standards and guidance, inspected and enforced by fully trained Fire and Rescue Service fire safety officers."

The Liberal Democrat manifesto is silent on building safety and fire prevention. 
p. 93. What role for housing in the 'Brexit' election? Spotlight on the party manifestos and what they mean for the housing sector

\section{Standards in the Private Rented Sector}

The government has focused a number of new regulations on standards in the private rented sector since 2017 and their 'Better Deal for Renters' confirms that they are standing by their proposal to abolish 'no fault' evictions. This also includes a proposal to require only one 'lifetime' deposit which moves with the tenant - a proposal bound to be popular with renters. This will go alongside strengthening rights of possession for landlords.

The Labour leadership has expressed its determination to shift power away from landlords to tenants. Labour plans to introduce rent controls by capping rents with inflation; cities would also be given powers to cap rents further. New open-ended tenancies would provide security and stop 'no fault' evictions and new minimum standards would be enforced through nationwide licensing and tougher sanctions on landlords. A renters' union would be set up across the country to allow renters to "organise and defend their rights." It is noteworthy that the Residential Landlords Association reacted to this by claiming that the plans would "threaten to close down the private rented sector".

Labour would also end the rule that requires landlords to check people's immigration status or that allow them to exclude people on housing benefit, with the intention of ending this level of discrimination in the private rented sector.

Labour backed down on plans to develop a new Right to Buy scheme for private tenants to buy their rented properties from landlords.

The Liberal Democrat manifesto pledges mandatory licensing to improve protections against rogue landlords. It also suggests increasing minimum energy efficiency standards and a new Help to Rent scheme with government-backed tenancy deposit loans for all first-time renters under 30. Longer tenancies of three years or more "with an inflation-linked annual rent increase built in" would aim to give tenants security and limit rent hikes.

\section{Decent Homes}

The Conservative manifesto pledges to bring forward the long-awaited Social Housing White Paper following consultation on the Green Paper back in 2018. This is described as setting out measures to empower tenants including greater redress, better regulation and improving the quality of social housing through a revised decent homes standard. It also refers to the continued supply of social homes.

The social housing sector has been waiting for these proposals for some time, and in the meantime have been told to 'just get on with it' in terms of revising tenant complaint and engagement strategies. The social housing sector will await with interest what form the new 'better regulation' framework takes and whether performance indicators, expressed as league tables have made it to the final cut.

Under Labour, homes would be built to higher standards according to a new Decent Homes programme. Tenants would be empowered to impact the management of social housing and regeneration schemes would be carried out according to their needs. Labour wants housing associations to be much clearer and closer to their social purpose.

Under Liberal Democrats, standards of social housing would be made clearer and regulations to protect renters would be enforced. They aim to fully recognise tenant panels so that renters have a voice in landlord governance and require complaints to be dealt with in a timely manner. 
p. 94. What role for housing in the 'Brexit' election? Spotlight on the party manifestos and what they mean for the housing sector

\section{Capacity of Local Services and Local Powers}

\section{Levelling-up across the regions}

In a welcome move from the main parties, regional concerns are high on the agenda with all the main parties pledging to invest in regional programmes.

Labour's manifesto includes a pledge to "level-up across the country" by ensuring investment is evenly spread across the regions as well as bringing about a "radical decentralisation of power." This will be supported by the launch of a Local Transformation Fund in each region to fund infrastructure projects. A National Transformation Fund Unit would be based in the North of England and would provide a regional voice in Whitehall.

They aim to bring services back into the remit of local councils. This would entail making funding for local authorities more "reactive" in order to respond to sharp rises in demand for services. They aim to "rebalance power in the planning system by giving local government greater freedom to set planning fees and by requiring the climate and environmental emergency to be factored into all planning decisions."

The Liberal Democrat manifesto also plans to give local authorities and regions the powers to make decisions about their areas with a capital $£ 50$ billion Regional Rebalancing Programme. They aim to "continue to champion investment in the Northern Powerhouse." They pledge to "end the continual erosion of local government funding and commit to a real increase in local government funding over key levers of economic development such as housing".

The Conservative manifesto continues the commitment made in the last Queen's Speech for full devolution across England with the publishing of an English Devolution White Paper next year. Through bodies like the Northern Powerhouse, there will be a drive for greater levels of foreign investment into the UK, promoting towns, cities. As part of plans for full devolution, proposals will be invited from local areas for growth bodies similar to the Oxford-Cambridge Arc.

Any commitment which aims to 'level-up' support will be good news for Northern housing providers. Government policy aims much support to areas of 'highest affordability pressure' and in doing so leaves large parts of the country ill-equipped to deal with their own challenges - addressing regional diversity and the nuances of affordability in all regions is long overdue.

\section{Place-making}

The Conservative manifesto confirmed its commitment to regenerating towns with the Towns Fund going to an initial 100 towns to improve their local economy. They have committed to 'Infrastructure First' by amending planning rules so that the infrastructure - roads, schools, GP surgeries - comes before people move into new homes and a new $£ 10$ billion Single Housing Infrastructure Fund will help deliver it.

Those Northern towns selected to receive funding from the Towns Fund will be making the most of the investment but regeneration programmes take place over many years and we will be looking for a commitment over the long-term - beyond the life of one Parliament - for those towns in need of the greatest intervention to regenerate housing and places.

The Liberal Democrats have committed to reform planning to ensure developers are required to provide essential local infrastructure from affordable homes to schools, 
p. 95. What role for housing in the 'Brexit' election? Spotlight on the party manifestos and what they mean for the housing sector

surgeries and roads alongside new homes. They will set up a £2bn Rural Services Fund to enable the co-location of services in local hubs.

Labour would set up a Local Transformation Fund in each English region to be used exclusively to fund infrastructure projects decided at a local level.

There is commitment from Northern local authorities to meet the transformative challenge, but additional capacity will be necessary. The government's policy assumption in targeting support to high affordability areas is that other places do not require robust housing and planning services. This is a deeply flawed approach. The challenges of land viability, housing renewal and delivering new build in the North requires skills and properly resourced housing and planning departments.

Housing associations look to local authorities for place leadership, even though councils have faced much reduced funding. Northern councils have had to adapt rather than buckle, but 80 per cent of capacity is now in statutory services with spending on housing and planning greatly depleted.

On behalf of Northern providers, we will be calling for a real-terms increase for councils through next year's Spending Review, a truly national centre of specialist expertise and place-based, outcome focused, long-term deals to build local capacity.

The North's councils have shown an unbelievable ability to adapt and carry on. But, when faced with the prospect of huge increases in delivery, the capacity just isn't there yet. That's why we need to create it.

\section{Homelessness}

Some common pledges emerge from the main parties with all committing to ending rough sleeping.

The Labour manifesto plans to end rough sleeping within five years through a national plan by a prime minister-led taskforce. Hostels would be expanded and upgraded with 8,000 additional homes to be made available for people with a history of rough sleeping. The Local Housing Allowance would be raised in line with the $30^{\text {th }}$ percentile of local rents and an additional $£ 1$ billion a year would be earmarked for councils' homelessness services.

They plan to repeal the Vagrancy Act and amend anti-social behaviour legislation to stop the law being used against those who are homeless.

The Liberal Democrat manifesto includes a plan to introduce a "somewhere safe to stay" legal duty to ensure that everyone who is at risk of sleeping rough is provided with emergency accommodation and to ensure that local authorities have the resources to deliver the Homelessness Reduction Act as well as providing accommodation for survivors of domestic abuse. They would also scrap the Vagrancy Act.

The Conservatives have already pledged to fully support and implement the Homelessness Reduction Act. They also aim to end rough sleeping by the end of the next Parliament by expanding pilots and programmes such as the Rough Sleeping Initiative and Housing First and working to bring together local services to meet the health and housing needs of people sleeping on the streets. A new stamp duty surcharge levied on overseas buyers would go towards helping to fund support for rough sleepers. 
p. 96. What role for housing in the 'Brexit' election? Spotlight on the party manifestos and what they mean for the housing sector

\section{In conclusion}

All main parties are talking about the need for more housing and it is positive - and a huge change in emphasis since the last election in 2017 - that the promise of more social housing is so high on the political agenda. There is a welcome commitment by the Conservatives to extend the Affordable Homes Programme. No detail is provided on what this will look like but the social housing sector in the North will be looking for a fair affordable homes programme which continues to support the North with its housebuilding ambitions.

The elephant in the room is the funding commitments needed to deliver these pledges and the capacity of local services including construction workers to fulfil the promises. The public sector simply doesn't have the capacity to ramp up its housing delivery by so much, so quickly but has an ambition and drive to do so.

All parties would face considerable challenges in delivering investment on this scale - whether that be the challenge of finding worthwhile projects in which to invest, or the challenges posed by shortages of suitably skilled workers in the construction industry.

Party commitments also need to be set in the context of independent assessment that 140,000 additional affordable homes are needed each year in England; of which around 19,000 must be delivered in the North.

Under the Conservative, 'let's not to rock the boat' manifesto, austerity may be at an end, but unfreezing the freezes imposed previously still leaves public service spending lower than it would otherwise be at this point.

Under Labour both taxes and spending would rise to new highs. In framing their manifesto, Labour is undoubtedly aware that proposals are offered which are not realistically deliverable in the short term and should be regarded as longer-term ambitions for change rather than a programme for a five-year Parliament. The Institute for Fiscal Studies described their commitments as not 'properly credible'.

All the main parties are talking about regional priorities and Northern issues, with promises to 'level-up' the regions, having started as a Conservative pledge has now spread to the Labour manifesto.

The Labour manifesto is the most radical on social housing delivery, standards in the private rented sector, and support for those on low income and benefits. Clearly the party feels that social housing policy is its strong point and wanted to 'go big' on this aspect. Labour has also produced new "regional manifestos" with promises on housing - as well as transport and jobs - for each area of the country - a welcome addition to the main pledges.

The Conservative manifesto confirms a continuation of the policy programme that was underway prior to the election with a focus on new build housing and home ownership. It may be of concern though that the tone of the manifesto on housing is not just about not rocking the boat, but that the transition from a May to Johnson government has seemingly pushed housing down the list of priorities. It has certainly signalled a return to a clear focus on home ownership and away from social tenure which the last embers of the May government had just begun to nurture.

The Liberal Democrats managed to elicit support from former Conservative deputy prime minister Michael Heseltine to give them a boost when he called on the public to vote for the party, rather than back Conservatives, although this was Brexit-related and not housing-related. 
p. 97. What role for housing in the 'Brexit' election? Spotlight on the party manifestos and what they mean for the housing sector

With promised investment in public services across the board, this signals an end to a policy of austerity which will be necessary to deliver the council-house building revolution and planning reform which the main parties agree is needed to end the housing crisis. The sector will now be looking at how an incoming government will create the capacity in our councils to deliver the affordable and social housing desperately needed.

\section{Notes}

1 National Infrastructure Commission

* Correspondence address: Tracey Harrison, Northern Housing Consortium Ltd, Loftus House, Colima Avenue, Sunderland Enterprise Park, Sunderland, SR5 3XB. 